\title{
Consequences of Auditor Experience, Ethics and Organizational Commitment on Internal Audit Quality with Independent Variables as Moderator
}

\author{
Eka Desy Purnama \\ Faculty of Economics and Business, Universitas Kristen Krida Wacana, Jakara, Indonesia
}

\begin{abstract}
This study aims to analyze the influence of Influence Experience auditor, Ethics auditor and Organizational Commitment on the Quality of Internal Audit With Variable Moderator on Auditor Independence As the Government working in City Tangerang Inspectorate. All independent variables consisting of the auditor's experience, ethical auditors, and organizational commitment have a positive and significant influence on the dependent variable: the internal audit quality. In addition, the results showed that independent variables did not amplify the effect of each independent variable on the dependent variable but rather strengthened the combined effect of all independent variables on the dependent variable.
\end{abstract}

Keywords: experience of auditors, auditor ethics, organizational commitment, auditor independence and quality of internal audit

DOI: $10.7176 /$ RJFA/12-23-02

Publication date: December $31^{\text {st }} 2021$

\section{INTRODUCTION}

The state budget managed by the government includes a fairly large amount of funds. Accountability for the use of funds for government administration should be supported by sufficiently reliable supervision to ensure an equitable distribution of funds in all public sectors so that the effectiveness and efficiency of the use of funds can be accounted.

The government auditors consist of the Inspectorate General of the Department, and the Internal Supervisory Unit (ICU) within State institutions and State-Owned Enterprises (SOE)/Regional Owned Enterprises (ROE), Provincial Inspectorate, Regency/City Regional Inspectorate, Financial and Development Supervisory Agency (FDSA) and the Supreme Audit Agency (SAA) which are independent external audit institutions.

Mardiasmo (2000) explains several weaknesses in government audits in Indonesia. Firstly, these weaknesses include the unavailability of adequate performance indicators as a basis for measuring government performance, both central and local governments. Secondly, it relates to the problem of the structure of the audit agency for the central and local governments in Indonesia. The problem that often occurs is that many functional audit institutions overlap in carrying out audits, which causes inefficiency and ineffectiveness of auditing.

Regulation of the Minister of State for the Empowerment of State Apparatus No. PER/05/M.PAN/03/2008 states that the government's internal control is an important management function in government administration. Through internal control, it can be seen whether a government agency has carried out activities under its duties and functions effectively and efficiently and following the plans, policies that have been set, and provisions. In addition, internal control over government administration is needed to encourage the realization of good governance and clean government and to support effective, efficient, transparent, accountable, and clean governance and free from corrupt practices, collusion, and nepotism. Internal audit is one form of effort to prevent fraud and misuse of state assets. Therefore, it takes people who can have special expertise in preventing things that result in losses that can occur in the government environment (Sawyer, 2009).

The work of a qualified or unqualified auditor will affect the auditor's conclusion. It will indirectly affect whether or not the decisions taken by parties outside the company are appropriate so that the auditor is required to have a sense of responsibility (accountability) in carrying out their work and have a professional attitude in order to reduce violations or irregularities that can occur in the auditing process so that accountability and professionalism are important elements that an auditor must possess.

One of the causes of low audit results is the auditor's experience factor. Several studies have shown that work experience has a positive effect on audit quality.

Nataline's research (2007) stated that inexperienced auditors would make greater error attributions than experienced auditors. According to Mulyadi (2008), an auditor must have experience in auditing activities; besides, formal education must also be possessed by an accountant profession because these two things are important and complementary. While Lehman and Norman (2006) in Mabruri and Winarna (2010), regarding the influence of experience and complexity of problems as well as audit judgment, show that experienced auditors (expertise) will more clearly detail the problems faced compared to inexperienced auditors, which will affect on 
auditor judgment.

In addition to the experience factor, auditor independence also has a role in delivering audit results. The report's objectivity must increase the confidence in the audit results made. Arens et al., (2011) define independence in auditing as the use of an unbiased perspective in conducting audit tests, evaluating the results of these tests, and reporting audit findings. High organizational commitment possessed by auditors who work in professional organizations will also have high organizational commitment.

The roles and functions of the Provincial, Regency/City Inspectorates are generally regulated in Article 4 of the Regulation of the Minister of Home Affairs Number 64 of 2007. In the article, it is stated that in carrying out the task of supervising government affairs, the Provincial, Regency/City Inspectorate has the following functions: (1) Planning surveillance program; (2) The formulation of policies and monitoring facilities; (3) Inspection, investigation, testing, and assessment of supervisory duties

Based on the description above, the Tangerang City Inspectorate is considered very representative to represent the government's internal supervisory group. This research will use the Tangerang City Inspectorate as the object of research representing the Government's Internal Supervisory Agency in Tangerang City.

This study will explore the consequences of auditor experience, ethics, and organizational commitment to the quality of internal audits with the independent variable as a moderator. The problems in the research are: (1) Does the experience of the auditor affect the quality of the results of the internal audit?; (2) Does auditor ethics affect the quality of the internal audit?; (3) Does organizational commitment affect the quality of internal audit results?; (4) Does auditor independence moderate or strengthen the effect of auditor experience on the quality of audit results?; (5) Does auditor independence moderate or strengthen the influence of auditor ethics on the quality of audit results?; (6) Does auditor independence moderate or strengthen the effect of organizational commitment on the quality of audit results?

\section{THEORETICAL REVIEW AND HYPOTHESES}

\section{Auditor Experience}

Knoers and Haditono (1999) in Singgih and Bawono (2010) states that experience is a learning process that adds to the development of potential behavior from both formal and non-formal education, or it is also interpreted as a process that leads a person to a higher pattern of behavior. A person's work experience shows how long, skilled and how many types of work have been done by someone to provide opportunities for that person to do his job better.

According to Suraida (2005), audit experience is the auditor's experience auditing financial statements. Both in terms of the length of time and the number of assignments that have been handled. Auditors gain audit experience during their audit assignments. Experience will be gained if the assignment and supervision procedures go well. The assignment procedure is a procedure that ensures a balance between the needs, expertise, development, and utilization of personnel in the implementation of the engagement.

\section{Auditor Ethics}

In general, ethics describes an embodiment and determination of a norm of attitude and behavior that helps humans act freely and responsibly because every action is born from a free personal decision. According to the AICPA (American Institute of Certified Public Accountants) Code of Professional Ethics in Seprian (2007), the ethical principles are as follows: responsibility, public interest, integrity, objectivity and independence, due care, scope, and nature of services.

\section{Organizational Commitment}

Organizational commitment is often identified by requiring some degree of agreement with the goals and values of the organization or profession, including morals and ethical values. Organizational commitment has three distinguishing factors: (1) Strong belief in and acceptance of the organization's goals and values. (2) Willingness to strive for the organization, (3) Strong ability to maintain membership in the organization (Ferris and Aranya, 1983 in Trisnaningsih, 2007).

The auditor's commitment to the organization is a form of an auditor's loyalty to his organization; besides, it will also foster loyalty and encourage the auditor's self-involvement in making various decisions. Therefore, commitment will create a sense of belonging for the auditor to the organization. So organizational commitment is the relationship between employees and the organization shown by a strong desire to maintain membership, accept the organization's values and goals, work hard to achieve organizational goals, and are willing to work hard to achieve organizational goals and continuity.

\section{Auditor Independence}

Great responsibility is important for auditors who work in a government agency or institution to have high independence and expertise. If the auditor is not independent of his client's management, his opinion is 
meaningless. In Seprian (2007), auditor independence includes two aspects, (1) independence of mental attitude and (2) independence of appearance.

Each auditor must maintain integrity and objectivity in his professional duties, and each auditor must be independent of all conflicting interests or improper influence. He must also avoid situations that may give third parties the impression that a conflict of interest or objectivity is untenable.

\section{Internal Audit Quality}

According to Tugiman (2006) in the research of Irafah et al. (2020), Internal auditing or internal examination is an independent assessment function within an organization to test and evaluate the organization's activities carried out. The Internal Auditor performs the internal audit function as described in the Indonesian Government Internal Audit Standard (2014:3) Internal audit is an independent and objective activity in the form of assurance activities and consulting activities designed to provide added value.

Furthermore, improve the operations of an organization (audit). This activity helps the organization (audit) achieve its objectives by using a systematic and orderly approach to assess and improve the effectiveness of risk management, control (control), and governance (public sector) processes.

The research of Alim et al. (2007) defines audit quality as the probability that the auditor will find and report violations in the auditee's auditing system. Audit quality can be seen in two dimensions. First, the auditor must be able to detect material misstatements. Second, the misstatements must be reported. The ability to detect material misstatements is strongly influenced by the auditor's technological capabilities, audit procedures, and the amount of sampling used. The ability to report material misstatements appropriately depends on the attitude of the auditor's independence, and if the auditor is under personal, emotional, and financial pressure, the auditor may lose his independence. Meanwhile, Deis and Groux (in Alim et al., 2007) explain that the probability of finding a violation depends on the technical ability of the auditor, and the probability of reporting a violation depends on the independence of the auditor.

\section{Research Hypothesis}

The hypotheses proposed in this study are as follows:

H1: Auditor experience positively affects the quality of internal audit results

$\mathrm{H} 2$ : Auditor Ethics has a positive effect on the quality of Internal audit

H3: Organizational commitment positively affects the quality of Internal audit results

H4: Auditor independence moderates or strengthens the effect of auditor experience on the quality of audit results.

H5: Auditor independence moderates or strengthens the influence of auditor ethics on the quality of audit results

H6: Auditor independence moderates or strengthens the effect of Organizational Commitment on the quality of audit results

\section{METHOD}

A population is a whole group of entities that can be in the form of people, events, or objects with certain characteristics, which are in an area and meet certain requirements related to research problems, Erlina (2011). The population in this study were the auditors of the Tangerang City Regional Inspectorate, amounting to 150 people. The sample in this study was determined using the Slovin formula so that the number of samples obtained was 115 responses.

The sampling technique was carried out by non-probability sampling method with Incidental sampling. Incidental sampling is a sampling technique that provides opportunities for anyone who is considered suitable to be the object of research - data analysis method, using Smart PLS (Partial Least Square) version 3.2.9.

\section{RESULTS AND DISCUSSION}

\section{Outer Model Test Results}

a. Convergent Validity Test Results

In testing the Convergent Validity of the measurement model with reflexive indicators is assessed based on the correlation between the item score or component score with the construct score calculated by PLS. Individual indicators are considered valid if they have a correlation value above 0.70 . The output results of the correlation between indicators and their constructs, all indicators are valid, and all indicators have met convergent validity because they have a loading factor value above 0.50 .

\section{b. Discriminant Validity Test Results}

In testing discriminant validity, reflective indicators are shown in the cross-loading between the indicators and their constructs. An indicator is declared valid if it has the highest loading factor for the intended construct compared to the loading factor for other constructs. Thus, latent constructs predict their block indicators better than other ones. 
Table 1. The Result of Discriminant Validity Test (Fornell Lacker Criterium)

\begin{tabular}{lccccc}
\hline & $\begin{array}{c}\text { Auditor } \\
\text { ethics } \\
(\mathrm{X} 2)\end{array}$ & $\begin{array}{c}\text { Auditor } \\
\text { Independence } \\
(\mathrm{X} 4)\end{array}$ & $\begin{array}{c}\text { Organizational } \\
\text { commitment } \\
(\mathrm{X} 3)\end{array}$ & $\begin{array}{c}\text { Internal } \\
\text { audit quality } \\
(\mathrm{Y})\end{array}$ & $\begin{array}{c}\text { Auditor } \\
\text { Experience } \\
(\mathrm{X} 1)\end{array}$ \\
\hline Auditor ethics (X2) & $\mathbf{0 . 8 1 5}$ & & & & \\
Auditor Independence (X4) & 0.774 & $\mathbf{0 . 7 1 8}$ & & & \\
Organizational commitment & 0.747 & 0.673 & $\mathbf{0 . 8 1 5}$ & & \\
(X3) & & & & & \\
Internal audit quality (Y) & 0.781 & 0.695 & 0.742 & $\mathbf{0 . 7 2 8}$ & $\mathbf{0 . 8 2 6}$ \\
Auditor Experience (X1) & 0.717 & 0.664 & 0.730 & 0.795 & \\
\hline
\end{tabular}
Source: PLS Output

From Table 1, it can be concluded that each construct is greater than the correlation between one construct and another in the model. Based on the table above, the AVE value can be concluded that the constructs in the estimated model meet the discriminant validity criteria.

c. Composite Reliability Test Results and Cronbach's Alpha

In testing composite reliability and Cronbach's alpha aims are to test the instrument's reliability in a research model. If all latent variables have a composite reliability value and Cronbach's alpha 0.7 , the construct has good reliability, or the questionnaire used as a tool in this study is reliable or consistent.

Table 2. The Result of Composite Reliability and Cronbach's Alpha Test

\begin{tabular}{lccc}
\hline \multicolumn{1}{c}{ Variable } & $\begin{array}{c}\text { Cronbach's } \\
\text { Alpha }\end{array}$ & $\begin{array}{c}\text { Composite } \\
\text { Reliability }\end{array}$ & Information \\
\hline Auditor Ethics (X2) & 0.956 & 0.962 & Reliable \\
Auditor Independence (X4) & 0.861 & 0.892 & Reliable \\
Organizational Commitment (X3) & 0.936 & 0.946 & Reliable \\
Internal audit quality (Y) & 0.886 & 0.909 & Reliable \\
Auditor Experience (X1) & 0.946 & 0.955 & Reliable \\
\hline
\end{tabular}

Source: PLS Output

Based on Table 2, the results of the composite reliability test and Cronbach's alpha show a satisfactory value because all latent variables have a composite reliability value and Cronbach's alpha 0.70 . It means that all latent variables are said to be reliable.

\section{Structural Model Testing or Hypothesis Testing (Inner Model)}

The test of Inner model is the development of the concept and theory-based models to analyze the relationship between exogenous and endogenous variables described in a conceptual framework. The steps for testing the structural model (inner model) are as follows:

a. Test Results R-square value. Look at the R-square value, which is the goodness-fit test of the model.

Table 3. $\mathrm{R}^{2}$ Value of Endogenous Variables

\begin{tabular}{lc}
\hline \multicolumn{1}{c}{ Endogenous Variables } & R-square \\
\hline Auditor Independence (X4) & 0.765 \\
Internal audit quality (Y) & 0.689 \\
\end{tabular}

Source: PLS Output

The structural model indicates that the model on the variables of Auditor Independence (X4) and Internal audit quality (Y) is moderately strong, having a value above 0.67 .

b. The Result of Goodness of Fit Model Test

In the Test of Goodness of Fit, the structural model on the inner model uses the predictive-relevance value $\left(\mathrm{Q}^{2}\right)$. A Q-square value greater than 0 (zero) indicates that the model has predictive relevance. The R-square value of each endogenous variable in this study can be seen in the following calculations:

The predictive relevance value is obtained by the formula:

$Q^{2}=1-(1-R 1)\left(1-R_{p}\right)$

$Q^{2}=1-(1-0.765)(1-0.689)$

$Q^{2}=1-(0.07308)$

$Q^{2}=0.926$

The calculation results above show the predictive-relevance value of 0.926 , greater than 0 (zero).

Thus, the model is feasible to have relevant predictive value.

c. The Result of Hypothesis Test (Estimated Path Coefficient)

The bootstrapping procedure can obtain the significance value of this hypothesis. The significance of the hypothesis is looked at the parameter coefficient values and the T-statistical significance value in the 
bootstrapping report algorithm. The significance of the T-table at alpha $0.05(5 \%)-1.96$, the T-table is compared with the T-count (T-statistics).

Table 4. The Result of Hypothesis Test

\begin{tabular}{|c|c|c|c|c|c|}
\hline & $\begin{array}{l}\text { Original } \\
\text { Sample }(\mathrm{O})\end{array}$ & $\begin{array}{l}\text { Standard } \\
\text { Deviation } \\
\text { (STDEV) }\end{array}$ & $\begin{array}{l}\text { T Statistics } \\
(|\mathrm{O} / \mathrm{STDEV}|)\end{array}$ & $\begin{array}{c}\mathrm{P} \\
\text { Values }\end{array}$ & Information \\
\hline $\begin{array}{l}\text { Auditor Ethics (X2) } \rightarrow \text { Auditor } \\
\text { Independence (X4) }\end{array}$ & 0.874 & 0.116 & 7.508 & 0.000 & $\begin{array}{l}\text { Significant } \\
\text { positive }\end{array}$ \\
\hline $\begin{array}{l}\text { Auditor Ethics }(\mathrm{X} 2) \rightarrow \text { Internal } \\
\text { audit quality }(\mathrm{Y})\end{array}$ & 0.436 & 0.148 & 2.945 & 0.003 & $\begin{array}{l}\text { Significant } \\
\text { positive }\end{array}$ \\
\hline $\begin{array}{l}\text { Auditor Independence }(\mathrm{X} 4) \rightarrow \\
\text { Internal audit quality }(\mathrm{Y})\end{array}$ & 0.468 & 0.157 & 2.988 & 0.003 & $\begin{array}{l}\text { Significant } \\
\text { positive }\end{array}$ \\
\hline $\begin{array}{l}\text { Organizational commitment } \\
(\mathrm{X} 3) \rightarrow \text { Internal audit quality } \\
(\mathrm{Y})\end{array}$ & 0.337 & 0.182 & 1.853 & 0.064 & No Effect \\
\hline $\begin{array}{l}\text { Auditor Experience (X1) } \rightarrow \\
\text { Internal audit quality (Y) }\end{array}$ & 0.481 & 0.173 & 2.775 & 0.003 & $\begin{array}{l}\text { Significant } \\
\text { positive }\end{array}$ \\
\hline $\begin{array}{l}\text { Auditor ethics (X2) } \rightarrow \text { Auditor } \\
\text { Independence (X4) } \rightarrow \text { Internal } \\
\text { audit quality (Y) }\end{array}$ & 0.409 & 0.143 & 2.858 & 0.003 & Mediation \\
\hline
\end{tabular}

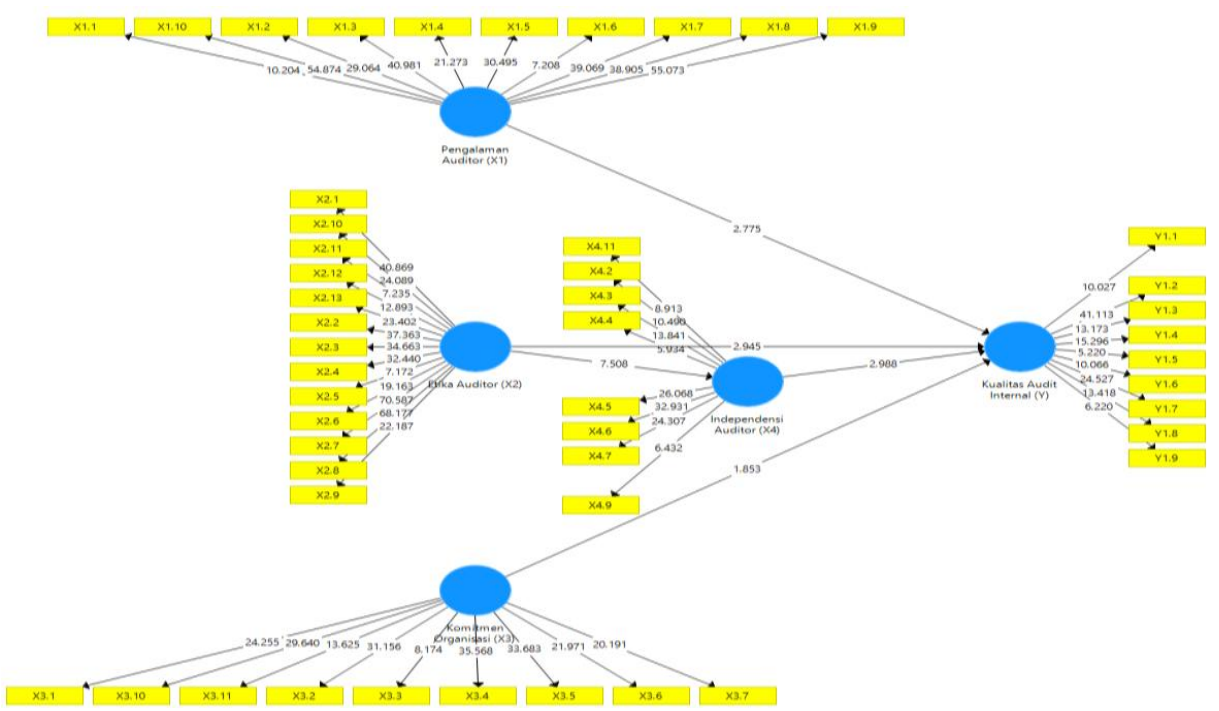

Figure 1. Bootstrapping Test

\section{Discussion of Research Results}

\section{The Effect of Auditor Ethics on Auditor Independence}

Based on the hypothesis test in this study, the results of the T-statistic value were 7.508 , the original sample value was 0.874 , and the $\mathrm{P}$ Values were 0.000 . The T-statistic value is greater than the T-table value of 1.96 , the original sample value shows a positive value, and the $P$ Values value shows less than 0.05 .

This result indicates that auditor ethics positively and significantly affect auditor independence.

\section{The Effect of Auditor Ethics on Internal Audit Quality}

Based on the hypothesis test in this study, the results of the T-statistic value were 2,945, the original sample value was 0.436 , and the $\mathrm{P}$ Values were 0.003 . The T-statistic value is greater than the T-table value of 1.96 , the original sample value shows a positive value, and the P-values value is less than 0.05 . This result indicates that auditor ethics has a positive and significant effect on the quality of internal audits.

\section{The Effect of Auditor Independence on the Quality of Internal Audit}

Based on the hypothesis test in this study, the T-statistic value was 2,988 , the original sample value was 0.468 , and the $\mathrm{P}$ Values were 0.003 . The T-statistic value is greater than the $\mathrm{T}$-table value of 1.96 , the original sample 
value shows a positive value, and the $\mathrm{P}$ Values value shows less than 0.05 . This result indicates that Auditor Independence has a positive and significant effect on the quality of internal audits.

\section{The Effect of Organizational Commitment on Internal Audit Quality}

Based on the hypothesis test, the results of the T-statistic value of 1.853 , the original sample value of 0.337 , and the $\mathrm{P}$ Values of 0.064 . The T-statistic value is less than the T-table value of 1.96 , and the P-values value is more than 0.05 . These results indicate that organizational commitment (X3) has no significant effect on the quality of internal audits.

\section{Effect of Auditor Experience on Internal Audit Quality}

Based on the hypothesis test, the results of the T-statistic value 2.775 , the value of the original sample 0.481 , and the value $\mathrm{P}$ Values of 0.003 . The T-statistic value is greater than the T-table value of 1.96 , the original sample value shows a positive value, and the $\mathrm{P}$ Values value shows less than 0.05 . This result indicates that the Auditor Experience (positive and significant effect on the internal audit quality.

\section{The influence of auditor ethics on the quality of internal audit through mediation by Auditor Independence}

Based on the hypothesis test in this study, the results of the T-statistic value were 2.858 , the original sample value was 0.409 , and the $\mathrm{P}$ Values were 0.003 . The T-statistic value is greater than the T-table value of 1.96 , the original sample value shows a positive value, and the $P$ Values value shows less than 0.05 . These results indicate that Auditor Independence can significantly strengthen the influence of Auditor Experience on the quality of internal audits.

\section{CONCLUSION}

From the results of hypothesis testing, it can be concluded that the auditor's experience, ethics have a positive and significant influence on the dependent variable, namely the quality of the internal audit. The organizational commitment variable has no significant effect on the quality of internal audits. In addition, this study also uses a moderating variable, namely auditor independence which strengthens or weakens the influence of the independent variable on the dependent variable. From the study results, it was found that the independent variables did not strengthen the influence of each independent variable on the dependent variable but strengthened the combined effect of all independent variables on the dependent variable.

\section{Suggestion}

The results of this study are used as a source of ideas for the development of future research. It is recommended that the next researcher add other variables not included in this study, for example, the use of information systems and internal control systems.

\section{Policy Implication}

The results of this study are expected to provide input to the government, especially the Tangerang City Inspectorate, to pay more attention to their employees, especially their work experience, ethics, and commitment to the organization to improve the quality of their internal audit. Especially senior auditors are expected to provide a lot of input or work experience for new auditors. In addition, the Tangerang City inspectorate must provide additional training or knowledge regarding ethics and commitment to the organization so that the performance of their internal audit results is preferable. The final step, of course, that must be done is to train the auditors' independence so that in conducting the audit, they are not influenced by the audited institution or other interested people.

\section{REFERENCES}

Agoes Sukrisno. (2008). Auditing Pemeriksaan oleh Kantor Akuntan Publik Jilid satu. Jakarta: Lembaga Penerbit Fakultas Ekonomi Universitas Indonesia.

Alim, M. N., Hapsari, T., \& Purwanti, L. (2007). Pengaruh Kompetensi dan Independensi terhadap Kualitas Audit dengan Etika Auditor sebagai Variabel Moderasi. SNA X Makassar.

Arens, Alvin A and Randal J Elder, Mark Beasley. (2011). Auditing and Assurance Services, An Integrated Approach, $14^{\text {th }}$ Ed. New Jersey: Prentice-Hall, Inc.

Arens, Alvin A. James L. Loebbecke. (2008). Auditing Pendekatan Terpadu, Terjemahan oleh Amir Abadi Yusuf, Buku Dua, Edisi Indonesia. Jakarta: Salemba Empat,.

Azwar, Saifuddin. (2005). Sikap Manusia: Teori dan Pengukurannya. Yogyakarta: Pustaka Pelajar

Bahtiar, Arif. (2002). Akuntansi Pemerintahan. Edisi I. Jakarta: Salemba Empat.

Dainton, Marianne \& Zelley, Elaine D. (2005). Applying Communication Theory for Professional Life: A Practical Introduction. SAGE.

Erlina. (2011). Metodologi Penelitian. Medan : Usu Press.

Firth M. (1980). Perception of Auditor Independence and Official Ethical Guidelines, The Accounting 
Review,pp. 451-66, July.

Gudono, M. dan Sihwajoeni. (2000). Persepsi Akuntan Terhadap Kode Etik Akuntan. Jurnal Riset Akuntansi Indonesia, 3 (2), 168-184,

Greenberg, Jerald dan Baron, Robert A. (2000). Perilaku Organisasi. Jakarta: Prentice Hall

Green, L.W., \& Kreuter, M.W. (2000). Health promotion planning aneducational and environmental approach. (2nd ed.). Mountain View: Mayfield Publishing Company.

Hasan, Iqbal. (2008). Analisis Data Penelitian dengan Statistik. Jakarta: PT. Bumi Aksara

Hiro Tugiman. (2006). Standar Profesional Audit Internal.Yogyakarta: Kanisius.

Hun Tong Tan, dan Alison Kao. (1999). Accountability Effect on Auditor's Performance: The Influence of Knowledge, Problem Solving Ability and Task Complexity, Journal of Accounting Reseach, 2:209-223.

Husein, Umar. (2008). Desain Penelitian MSDM dan Perilaku Karyawan, Seri Desain Penelitian Bisnis - No 1. Jakarta: PT Rajagrafindo Persada.

Ikatan Akuntan Publik Indonesia. (2004). Standar Profesi Akuntan Publik. Jakarta,

Irafah, S., Sari, E. N., \& Muhyarsyah, M. (2020). Pengaruh Kompetensi Sumber Daya Manusia, Peran Internal Audit, dan Kesuksesan Penerapan Sistem Informasi Keuangan Daerah terhadap Kualitas Laporan Keuangan. Jurnal Riset Akuntansi dan Keuangan, 8(2), 337-348.

Kalbers, Lawrence P., dan Fogarty, Timothy J. (1995). Professionalism Its Consequences: A Study of Internal Auditors. Auditing: A Journal of Practice, 14 (1), 64-86

Koroy, Tri Ramaraya. (2007). Pengaruh Preferensi Klien dan Pengalaman Audit terhadap Pertimbangan Auditor. Jurnal Riset Akuntansi Indonesia, 10 (1), 113-130.

Kriyantono, Rachmat. (2010). Teknik Praktis Riset Komunikasi. Jakarta: Prenada Media Group.

Lawrence B. Sawyer, Mortimer A. Dittenhofer, and James H. Scheiner. (2009). AuditInternal Sawyer”, Edisi Kelima. Jakarta: Salemba Empat.

Lehman, Constance M. dan Carolyn S. Norman. (2006). The Effects of Experiences on Complex Problem Representation and Judgment in Auditing: An Experimental Investigation. Behavioral Research in Accounting. Vol. 18: 65-83.

Lowenshon, S., Johnson E.L., dan Elder J.R. (2005). Auditor Specialization and Perceived Audit Quality, Auditee Satisfaction, and Audit Fees in the Local Government Audit Market

Luthans, Fred. (2005). Perilaku Organisasi. Yogyakarta: ANDI

Mardiasmo. (2000). Perpajakan Indonesia Revisi. Yogyakarta: penerbit Andi.

Mautz, R.K dan H.A. (1993). Sharaf. The Philosophy of Auditing. Sarasota: American Accounting Association.

Messier, et al., (2005). Jasa Audit dan Assurance: Suatu Pendekatan Sistematis. Edisi 4. Jakarta: Salemba Empat. Mulyadi. (2008). Auditing, Edisi keenam, Buku satu dan dua, Jakarta: Salemba Empat.

Nataline. (2007). Pengaruh Batasan Waktu Audit, Pegetahuan Akuntansi dan Auditing, Bonus, Serta Pengalaman Terhadap Kualitas Audit pada Kantor Akuntan Publik di Semarang. Fakultas Ekonomi Universitas Negeri Semarang.

Noor, Juliansyah. (2012). Metodologi Penelitian Skripsi. Tesis. Disertasi dan Karya Ilmiah. Jakarta: Kencana Prenada Media Group.

Notoatmodjo, Dr. Soekidjo.(2005). Metodologi penelitian kesehatan. Jakarta: Rineka Cipta

Nungky Nurmalita Sari. (2011). Pengaruh Pengalaman Kerja Independensi, Objektivitas, Integritas, Kompetensidan EtikaTerhadap Kualitas Audit. Skripsi. Fakultas Ekonomi. Universitas Diponegoro. Semarang.

Purnamasari, D. I. (2005). Pengaruh Partisipasi Terhadap Efektifitas Ststem Informasi Dengan Pengalaman Kerja Sebagai Variabel Pemoderasi. Jurnal Riset Akuntansi dan Keuangan, 1(1), 38-50.

Riduwan. (2009). Pengantar Statistika. Bandung: Alfabeta.

Santoso. Singgih. (2005). Menguasai SPSS dan Excell Untuk Mengukur Sikap dan Kepuasan Konsumen. Jakarta: PT. Elex Media Komputindo.

Satyanugraha, Heru. (2003). Etika Bisnis - Prinsip dan Aplikasi. Jakarta: LPFE Universitas Tri Sakti.

Singgih, E., \& Bawono, I. (2010). Faktor-faktor Dalam Diri Auditor dan Kualitas Audit. Universitas Jendral Sudirman Purwokerto.

Sososutikno, C. (2003). Hubungan Tekanan Anggaran Waktu dengan Perilaku Disfungsional serta Pengaruhnya terhadap kualitas Audit. Simposium Nasional Akuntansi VI. Surabaya

Sukriah, Ika, dkk. (2009). "Pengaruh Pengalaman Kerja, Independensi, Obyektifitas, Integritas dan Kompetensi Terhadap Kualitas Hasil Pemeriksaan”. Simposium Nasional Akuntansi XII. Palembang.

Suraida, Ida. (2003). Pengaruh Etika, Kompetensi, Pengalaman, Risiko Audit dan Skeptisisme Profesional Auditor Terhadap Ketepatan Pemberian Opini Akuntan Publik (Survay terhadap para akuntan publik di Indonesia). Disertasi. Bandung: Program Pascasarjana Unpad (Tidak Dipublikasikan),

Suraida, dkk. (2005). Dasar-dasar Audit.Edisi 1. Yogyakarta: BPFE UGM

Susiana dan Arleen Herawaty. (2007). Analisis Pengaruh Independensi, Mekanisme Corporate Governance, dan 
Kualitas Audit terhadap Integritas Laporan Keuangan. SNA X Makassar.

Trisnaningsih, Sri. (2007). Independensi Auditor dan Komitmen Organisasi Sebagai Mediasi Pengaruh Pemahaman Good Governance, Gaya Kepemimpinan dan Budaya Organisasi terhadap Kinerja Auditor. SNA X. Makassar.

Weygandt, Jerry J and Kieso, Donald E and Kimmel, Paul D. (2007). Pengantar Akutansi, Edisi Ketujuh. Jakarta: Salemba Empat. 